\title{
Evaluation of losses of replacement heifers in pastoral and peri-urban camel herds in semi-arid northern Kenya
}

\author{
Mumina G Shibia ${ }^{1,2}$, George Owuor ${ }^{2}$ and Bockline O Bebe ${ }^{3^{*}}$
}

\begin{abstract}
This study estimated heifer losses and associated determinants in peri-urban camel herds characterized by market orientation and domination of lactating camels grazing closer to urban market outlets for milk. In this evolving peri-urban camel production system in semi-arid Kenya, the proportion of heifers born that survives to breeding age is important in sustaining the herds and the extent to which households obtain tangible and intangible benefits from camel keeping. Data was obtained through progeny history recall on 2,000 heifer loss cases out of 4,398 heifers born between 1991 and 2009. The estimated heifer loss was 0.455 and was $11.8 \%$ higher $(P<0.0001)$ in peri-urban herds $(0.505 \pm 0.040)$ than in pastoral herds $(0.387 \pm 0.047)$. The extent of heifer loss was significantly associated with veterinary service access $(P<0.05)$, labour hire $(P<0.01)$ and state of security $(P<0.01)$. Results provide lessons for policy intervention to support evolution of peri-urban camel milk production. Improving infrastructure and the security situation is necessary to enhance delivery of veterinary service and feed supply interventions to peri-urban camel herds for production of milk and breeding stock.
\end{abstract}

Keywords: Camel heifer; Progeny history; Market-oriented production; Kenya

\section{Background}

Camels (Camelus dromedarius) are primary livelihood assets in the arid and semi-arid lands (ASALs) of northern Kenya. Camels provide pastoral communities with tangible benefits (income, milk, meat, hides and skins) and intangible benefits (status symbol, insurance, risk aversion and social capital). Traditionally, camels have been managed in nomadic systems characterized by subsistence production objectives and mobile herds in search of pastures, water and mineral licks in the vast rangelands of the ASALs.

Nomadic pastoral production of camels is highly vulnerable to recurring droughts and subsequent ethnic conflicts over water and pastures (Guliye et al. 2007; Thornton et al. 2007). This has contributed to forcing part of the pastoral communities to abandon the traditional nomadic pastoral production in search for businesses, employment opportunities, security and social

\footnotetext{
* Correspondence: obebeb@yahoo.com

${ }^{3}$ Livestock Production Systems Group, Department of Animal Sciences,

Egerton University, Box 536-20115, Egerton, Kenya

Full list of author information is available at the end of the article
}

amenities in the urban centres (Bebe et al. 2007; Seré et al. 2008). The migrating pastoral households have introduced camel keeping within the vicinity of urban centres where they keep lactating herds to supply milk to urban consumers. Grazing of the lactating herds is restricted within pastures around the urban centre, so as to remain closer to market outlets. This practice is marked with changes in production objectives from subsistence to market orientation. Breeding stock is reared within the herd (Bebe et al. 2007). The camel herd management practices just described have evolved into a peri-urban camel milk production system. In this evolving system, the proportion of camel heifers born that survive to first calving is important in sustaining the herds and the extent to which households obtain tangible and intangible benefits from their camel herds.

However, sourcing of breeding stock from pastoral herds is not a promising option for sustaining evolution of peri-urban camel herds for marketed milk production. The pre-weaning calf mortality is between $20 \%$ and $55 \%$ (Schwartz et al. 1983; Wilson 1986) and when sex 
disaggregated is between $20 \%$ and $30 \%$ for heifers (Kaufmann 2000, 2003). When post-weaning mortalities are added, the loss of potential replacement heifers in pastoral herds would be substantial, limiting the supply of breeding stock to peri-urban herds. The high loss of heifers in pastoral herds is attributed to diseases, drought starvation, predation, snake bites, theft and rustling, infertility, still births and deformities (Schwartz et al. 1983; Simpkin 1985; Baumann and Zessin 1992; Kaufmann 2003).

The nature of the heifer losses suggests a strong relationship with management practices. Because management strategies in peri-urban herds differ from those of pastoral herds, the effect on heifer production may differ and so are losses to first breeding age. Because peri-urban camel herders rear their own camel heifers (Bebe et al. 2007), they have to maximize survival rate of the heifers born to breeding age when they enter the milking herd. Therefore, the study compared the extent of camel heifer loss to first calving age and identified associated determinants of the differences between pastoral and peri-urban camel herds in semi-arid northern Kenya.

\section{Study area}

The study sampled representative peri-urban herds around Isiolo town and representative pastoral herds in the rangelands of Isiolo County of northern Kenya (Figure 1). Peri-urban herds are predominantly lactating herds kept closer to urban milk market outlets. Pastoral herds are mobile and grazed far away from urban centres. Milk from the herd is consumed by the herders and the family.

The peri-urban grazing areas receive median annual rainfall between 400 and $600 \mathrm{~mm}$ (Herlocker et al. 1993), while the rangeland grazing areas receive median annual rainfall of 150 to $250 \mathrm{~mm}$. In both peri-urban and rangeland grazing areas, the dominant vegetation are shrubs of Acacia reficiens, Acacia tortillis, Cammiphora spp. and Duospherma eremophilum and grasses of Aristida spp., Leptothrium senegalese, Sporobolus spp. and Lintonia nutans (Herlocker et al. 1993).

\section{Methods}

The data was processed and analyzed using STATA software (StataCorp LP, College Station, TX, USA) and fitted Tobit model to estimate heifer losses and to identify the determinants of heifer losses.

\section{Sampling procedure}

The desired sample size was determined on the basis of average female calf mortality estimate of 30\% taken from Kaufmann (2003) for pastoral camels in northern Kenya. Sampling was for two independent samples represented by pastoral and peri-urban herds. For economically important difference, we allowed for a 95\% chance of detecting mortality rate with a difference of $20 \%$ at $5 \%$ level of significance (Petrie and Watson 1999). Computation of the desired sample size with this approach yielded sample herds of 171, of which 94 were portioned to pastoral herds and 77 to peri-urban herds on proportional basis.

The herds representing pastoral and peri-urban camel production were sampled randomly with the help of the district veterinary and animal production officers in Isiolo. Herds were visited in the morning during times of milking. In each herd visited, the owner together with the herder was asked to recall progeny history of each breeding female for all calves born. The progeny history technique of Swift (1981) has been used successfully for herd dynamics data in pastoral systems and applied successfully for collecting progeny history because of good memory about individual animals by pastoralists (Kaufmann 2003, 2005; Tura 2008). Progeny history enabled profiling cases of female and male calves born by each of the breeding females in the herd. Case profiling captured the number of calves born by sex, the number lost before first calving, the age at time of loss, the cause of loss and access to support services in the grazing areas.

Implementation of the progeny history recall profiled 2,887 cases of breeding female camels and heifer losses of 729 and 1,271 in pastoral and peri-urban herds, respectively, between 1991 and 2009. The camels profiled were aged between 5 to 26 years, which represent 18 years record of calving.

\section{Theoretical framework and the Tobit model}

The individual herd owner's decision to enhance survival of breeding stock to first calving age was modelled using random utility model where utility of each option is assumed to be a linear function of observed individual characteristics plus an additive error term (Verbeek 2000). Random utility model assumes that decisionmakers choose options that maximize their perceived utility. In addition, decision-makers are assumed to know better the opportunities that meet their objectives. Since the exact form of a decision-maker utility function is not known, some assumptions were made where a random element to reflect the unobservable part of an individual's utility function was included and represented as Equation 1:

$$
U_{i j}=\overline{U_{i j}}+\varepsilon_{i j} \quad i=1, \ldots N \quad i=1,0,
$$

where $U_{i j}$ is the utility received by the $i$ th individual decision-maker from the $j$ th alternative options for securing survival of breeding stock, $\bar{U}_{i j}$ is the systematic part of the utility function and $\varepsilon_{i j}$ is the random part.

The individual's utility is also a function of the attributes to the alternative to the individual herd and herd 


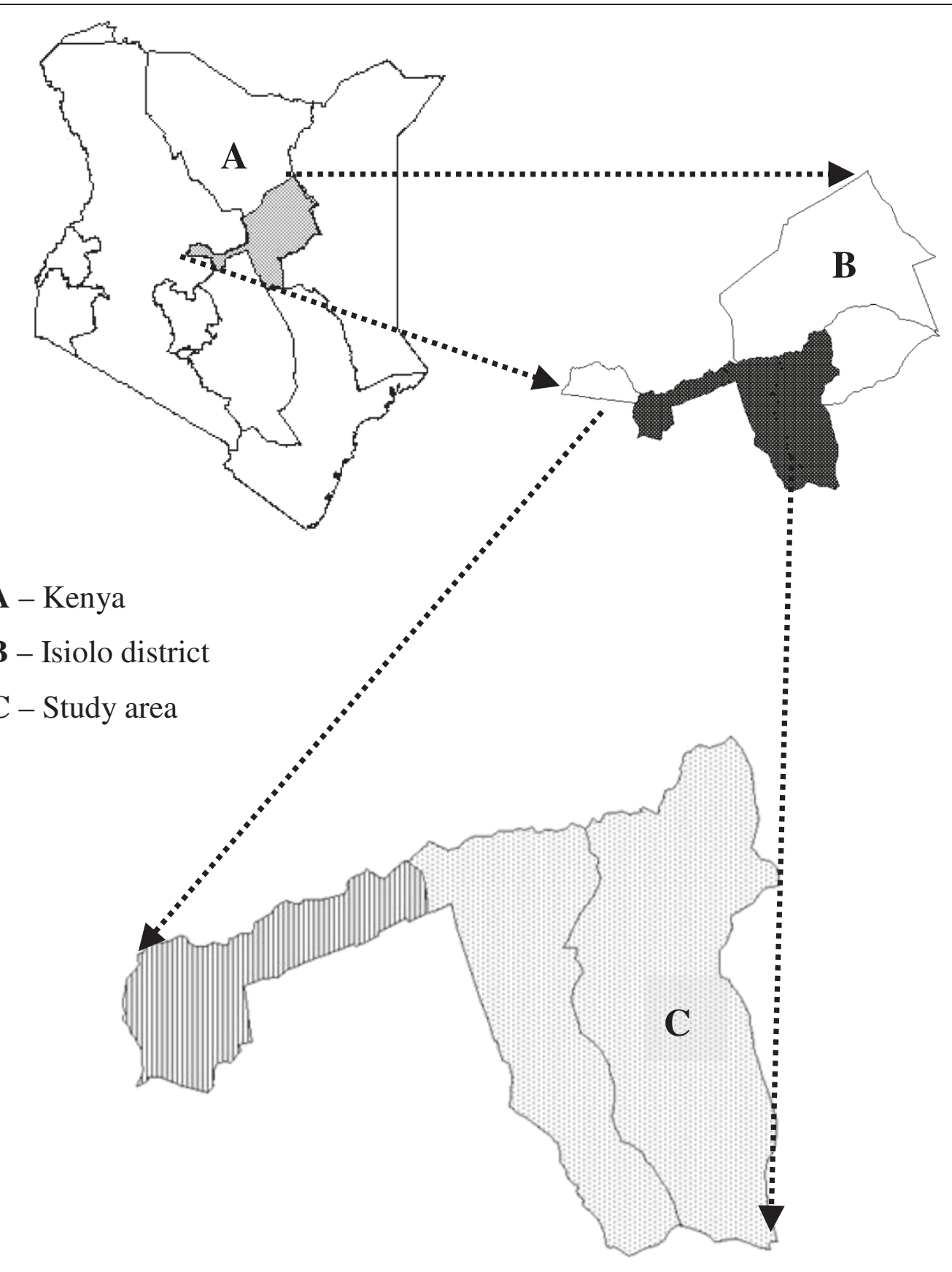

30

0

30

60 Miles

Study sites

E: Pastoral system - Gabatulla division

IIIII Peri-urbansystem - Isiolo central division

Pasoral system - Kinna division

Figure 1 Map of the study area showing pastoral and peri-urban camel systems. 
owner characteristics and livestock support programmes. The indirect random utility model for $U_{i j}$, the unobservable economic variable utility, was represented as Equation 2:

$$
U_{i j}=z_{i j}^{\prime} \alpha+c_{i}^{\prime} \beta_{j}+\varepsilon_{i j}
$$

where $z_{i j}$ represents the vector of attributes of alternative $j$ to the individual decision-maker $i, c_{i}^{\prime}$ is the vector of characteristics of individual herd and herd owner characteristics and livestock support programmes $i$ and $\alpha$, and $\beta_{j}(j=1,0)$ are vectors of unknown parameters. An earlier study of the same camel herds had indicated that peri-urban camel herds rear their own heifer replacements (Bebe et al. 2007). This heifer management practice requires that a camel keeper maximizes the survival rate of heifers born to the age at which they enter the milking herd. Therefore, an individual decisionmaker who owns a camel will maximize his/her utility by maximizing the survival of replacement heifers born which will support tangible and intangible benefits.

The owner maximizes his/her utility subject to constraints on voluntary losses, involuntary losses, herd and herd owner characteristics and support programmes. The individual herd owner's utility of options for securing survival of breeding stock was assumed to be a linear function of the herd owner's decision to reduce losses that resulted from voluntary and involuntary reasons, herd and herd owner characteristics and access to support services. Maximization of heifer survival $\Omega_{r}$ is therefore a function of age class $\left(x_{a}\right)$, voluntary losses $\left(x_{v}\right)$, involuntary losses $\left(x_{i}\right)$, herd and herd owner characteristics $\left(x_{h}\right)$ and support services $\left(x_{s}\right)$ expressed in Equation 3:

$$
\max \Omega_{r}\left(x_{a}, x_{v}, x_{i}, x_{h}, x_{s}\right)
$$

The heifers lost as a proportion of those born potentially range from 0 to 1 . The Tobit model was used on the basis of measurement of the dependent variable $y$ (ranging between 0 and 1 ) which was the proportion of heifers that failed to reach first calving age. Appropriateness of this model has been recommended where the dependent variable is proportionately determined, allowing for a lower limit of 0 and an upper limit of 1 (Maddala 1992; Gujarati 2003). The Tobit model was created by Tobin (1958) and has been applied in household purchasing decisions, extramarital behaviour, labour supply and criminal activities (Greene 1993, 2003). In context of agricultural economics, it has been applied in adoption studies (Ransom et al. 2003), commodity supply decisions (Mundlak 2002), disequilibrium models (Fair and Jafee Fair and Jaffee 1972), production economics (Paris 1992) and development economics (Goetz 1992) among others.
Based on Maddala (1992) the standard Tobit model was thus defined as Equation 4:

$$
Y_{i}=Y_{i}^{*}=\beta x_{i}+u_{i} \text { if } Y_{i}^{*}>0 .
$$

Otherwise,

$$
Y_{i}=0 \text { if } Y_{i}^{*} \leq 0 .
$$

$Y_{i}^{*}$ is a latent variable which cannot be observed, $\beta$ is a vector of unknown parameters to be estimated, $x_{i}$ is a vector of explanatory variables and $u_{i}$ is the random error term.

The model assumes the random error term $u_{i}$ and is normally and independently distributed with mean $=0$ and constant variance $\delta^{2}$ that is $u_{i} \sim \operatorname{IN}\left(0, \delta^{2}\right)$. If the nonobserved latent variable $Y_{i}^{*}$ is greater than 0 , the observed qualitative variable $Y_{i}$, which is indicative of the proportion of heifers lost, becomes a continuous function of the explanatory variables; $X_{i}$ represents vectors of herd type, herd characteristics and livestock support services accessible as Equation 5:

$$
\begin{aligned}
Y_{i}^{*} & >0=>Y_{i}=\text { Proportion of heifers lost } \\
& =Y_{i}^{*}=X_{i}^{\prime} \beta+\varepsilon_{i} .
\end{aligned}
$$

On the other hand, for $Y_{i}^{*}$ which was less than or equal to $0, Y_{i}$ was 0 , and when $Y^{*}$ was negative, the heifer losses in the camel herds were 0 which implied that all heifers reached the first calving age as Equation 6:

$$
\begin{aligned}
Y_{i}^{*} \leq 0 & =>Y_{i} \\
& =0\left(Y^{*} \text { can be negative only if } Y=0\right) .
\end{aligned}
$$

The Tobit model was estimated using the reduced Equation 7:

$$
Y=\beta_{i} X_{i}+\beta_{j} X_{j}+\beta_{k} X_{k}+\varepsilon,
$$

where $Y$ is the proportional loss (proportion of loss relative to births), $X_{i}$ is a vector of herd (pastoral and peri-urban), $X_{j}$ is a vector of herd owner characteristics, $X_{k}$ is a vector of support services accessed and $\varepsilon$ is the error term which is normally and independently distributed. The explanatory variables were as follows: $X_{i}=X_{1}$ pastoral herds, $X_{2}$ peri-urban herds; $X_{j}=X_{1}$ herd size, $X_{2}$ level of education of the owner of the camel herd, $X_{3}$ attendance to trainings/ workshops/seminars on camel calf management by the herd owner and $X_{4}$ type of labour used to carry out camel production activities; $X_{k}=X_{1}$ access to veterinary services/interventions, $X_{2}$ distance to watering points, $X_{3}$ distance to the nearest market and $X_{5}$ security situations for camel herds. A summary of description and 
Table 1 Description and measurement of variables used in the study

\begin{tabular}{|c|c|c|c|}
\hline $\begin{array}{l}\text { Variable } \\
\text { acronym }\end{array}$ & Variable meaning & Variable description & Variable measurement \\
\hline Herd & Grazing area where the herd is managed & Pastoral herd (0) peri-urban herd (1) & Categorical, dummy \\
\hline Proploss & Proportional loss & $\begin{array}{l}\text { Proportion of female calves lost relative to female } \\
\text { calves born }\end{array}$ & $\left(\frac{\text { Total number lost }}{\text { Total number born }}\right)$ \\
\hline Agec & Age class of heifer at the time of loss & $\begin{array}{l}1=\text { pre-weaning }<3 \text { months; } 2=\text { yearling, three to } \\
\text { two years; } \\
3=\text { three years; } 4=\text { four years; } 5=\text { age at first calving }\end{array}$ & Categorical \\
\hline Reason & Reason that led to loss of heifer & $\begin{array}{l}\text { Involuntary losses: } 1=\text { death from diseases, } 2=\text { death } \\
\text { from predation/injury/poisoning, } 3=\text { deaths from } \\
\text { drought starvation, } 4=\text { infertility/deformities, } 5=\text { theft/ } \\
\text { rustling, } 6=\text { voluntary losses (slaughtered for } \\
\text { ceremonies, gift out, leased, dowry payment) }\end{array}$ & Categorical \\
\hline Mktdist & Market distance & $\begin{array}{l}\text { Distance to the nearest market: } 0=\text { not far, } 1=\mathrm{far} \text {, } \\
2=\text { moderately far, } 3=\text { very far, } 4=\text { extremely far }\end{array}$ & $\begin{array}{l}\text { Ordinal measure, Likert scale } \\
\text { rating by camel herd owners }\end{array}$ \\
\hline Veterinary & Access to veterinary interventions & $\begin{array}{l}\text { Frequency of treatment of camel calves against } \\
\text { diseases: } 0=\text { None, } 1=\text { less frequently, } 2=\text { fairly } \\
\text { frequently (average), } 3=\text { frequently, } 4=\text { more } \\
\text { frequently }\end{array}$ & $\begin{array}{l}\text { Ordinal, Likert scale rating by } \\
\text { camel herd owners }\end{array}$ \\
\hline Herd & Gazing area where the herd is managed & Pastoral herd (0) peri-urban herd (1) & Categorical, dummy \\
\hline Security & Security situation for keeping camels & $\begin{array}{l}0=\text { not secured }, 1=\text { fairly secured }, 2=\text { secured } \\
3=\text { more secured, } 4=\text { highly secured }\end{array}$ & Categorical \\
\hline Train & $\begin{array}{l}\text { Attendance to trainings/workshops/ } \\
\text { seminars on camel calf management }\end{array}$ & No $=1$ and 0 otherwise & Categorical, dummy \\
\hline Labour & $\begin{array}{l}\text { Labour used in carrying out camel } \\
\text { management activities }\end{array}$ & Hired $=1$ and 0 otherwise & Categorical, dummy \\
\hline \multirow[t]{6}{*}{ Herd size } & \multirow[t]{6}{*}{ Herd size } & Mature bulls & \multirow{6}{*}{$\begin{array}{l}\text { The total number of camels for } \\
\text { the categories in column } 3\end{array}$} \\
\hline & & Young bulls & \\
\hline & & Breeding females & \\
\hline & & Heifers & \\
\hline & & Male calves & \\
\hline & & Female calves & \\
\hline \multirow[t]{5}{*}{ Educ } & \multirow[t]{5}{*}{ Level of education } & Informal & \multirow[t]{5}{*}{ Likert scale } \\
\hline & & Primary & \\
\hline & & Technical after primary & \\
\hline & & Secondary & \\
\hline & & Post secondary & \\
\hline Supplement & Supplementary feeding/grazing reserves & No $=1$ and 0 otherwise & Categorical, dummy \\
\hline
\end{tabular}

Table 2 Data description for the sample camel population characteristics

\begin{tabular}{llll}
\hline Variable & Pastoral herds & Peri-urban herds & Total sample \\
\hline Herds sampled $(N)$ & 94 & 77 & 171 \\
Breeding females profiled $(N)$ & 1,214 & 1,673 & 2,887 \\
Age of breeding females (mean \pm SD) (years) & $18.97 \pm 4.79$ & $17.81 \pm 3.99$ & $18.45 \pm 4.48$ \\
Herd size (mean \pm SD) $(N)$ & $45.86 \pm 30$ & $87.60 \pm 50$ & $72.57 \pm 48.3$ \\
Total calves born $(N)$ & 3,945 & 4,800 & 8,745 \\
Total female calves born $(N)$ & 1,882 & 2,516 & 4,398 \\
Total female calves lost before age at first calving $(N)$ & 729 & 1,271 & 2,000 \\
Estimated proportional heifer loss (mean \pm SD) & $0.387 \pm 0.047$ & $0.505 \pm 0.040$ & 0.455 \\
\hline
\end{tabular}


Table 3 Marginal effects of factors influencing loss of replacement heifers before first calving

\begin{tabular}{lllll}
\hline Variables & $\begin{array}{l}\text { Maximum } \\
\text { likelihood } \\
\text { coefficient }\end{array}$ & $\begin{array}{l}\text { Robust } \\
\text { standard } \\
\text { error }\end{array}$ & $\boldsymbol{Z}$ & $\boldsymbol{P}>|\mathbf{z}|$ \\
\hline Herd $(0,1)^{\mathrm{a}}$ & 0.0857 & 0.0254 & 3.37 & $0.000^{*}$ \\
Educ (scale) & -0.0039 & 0.0109 & -0.36 & 0.719 \\
Train $(0,1)$ & -0.0104 & 0.0088 & -1.18 & 0.237 \\
Veterinary services & -0.0551 & 0.0173 & -3.18 & $0.001^{* *}$ \\
accessed (scale) & & 0.0237 & 4.47 & $0.000^{*}$ \\
Labour ${ }^{\text {b }}(0,1)$ & 0.1059 & 0.0168 & -3.73 & $0.000^{*}$ \\
Security (scale) & -0.0627 & 0.0412 & 13.08 & 0.000 \\
\hline ccons & 0.5387 & &
\end{tabular}

Log likelihood $=-1,218.1793$; number of observations $=1,877$; LR chi square $(6)=113.39$; Prob $>$ chi square $=0.000$; pseudo $R^{2}=0.2024$. *Significance at $1 \%$; **significance at $5 \%$. ${ }^{\mathrm{a}} \mathrm{A}$ dummy variable indicating pastoral herd (0) and

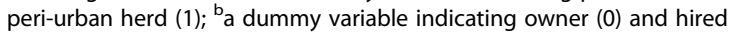
(1) labour.

measurement of variables used in the study is presented in Table 1.

\section{Results}

Descriptive analyses of the sample camel population

Table 2 presents a description of the sample camel population from which the proportions of lost heifers were estimated. Of all the female camel calves reported born, 0.455 failed to reach first calving, representing $54.5 \%$ of the potential heifer replacements surviving to enter the milking herd. The estimated heifer loss was $11.8 \%$ higher in peri-urban herds $(0.505 \pm 0.040)$ than in the pastoral herds $(0.387 \pm 0.047)$, and herd effect was significant (chi square value 60.55, $P<0.0001$ ).

\section{Determinants influencing loss of heifers before first calving}

Table 3 presents marginal effects of Tobit model estimates for factors influencing the loss of heifers. The diagnosis of the fitted model found the Tobit regression statistically significant $(P=0.0000)$, indicating that the combination of explanatory variables significantly affect the extent of heifer loss. The pseudo $R^{2}$ of 20.24 was above the statistical threshold of $20 \%$, confirming that the loss of heifers could be attributed to covariates fitted. Bivariate correlation analysis indicated that the herd (pastoral and peri-urban) variable had a high correlation coefficient with the distance to the nearest market $(0.75)$ and distance to the watering points $(0.60)$; therefore, variables of distance to market and to watering points were dropped from the model.

The coefficient for herd variable has a positive marginal value $(0.0857)$ and is significant $(P=0.000)$, indicating that loss of heifers was $8.6 \%$ higher in peri-urban than in the pastoral camel herds. The coefficient veterinary services has a negative marginal value $(-0.0551)$ and is significant $(P=0.000)$, indicating that loss of heifers was lower for camel herds that were accessing veterinary services. Therefore, access to veterinary services is essential to managing heifer loss, which in this study is associated with reduced heifer loss by $5.5 \%$.

Labour used for carrying out camel management activities has a positive marginal effect $(0.1059)$ and significantly influenced heifer loss $(P=0.000)$. Comparatively, hired labour increases heifer loss by $10.59 \%$ in camel herds. The coefficient of security threat situation for camels has a negative marginal effect $(-0.062)$ and is significant $(P=0.000)$, indicating that heifer loss was higher in unsecured camel herds. The findings imply that ensuring security situation from theft/rustling would decrease heifer loss by $6.2 \%$ in camel herds.

\section{Discussion}

Peri-urban herds are restricted to grazing near settled areas which could lead to over utilization of forage and feed resources. This could result in feed pressure and subsequently impact on survival of heifers. Restricted grazing of camel herds closer to urban market outlets can be associated with decreased mobility of pastoralists and reduced access to grazing reserves for dry seasons (Seré et al. 2008). This would imply that peri-urban herds were exposed to inadequate quantity and quality of year-round feeding necessary to support lactating camels concentrated around Isiolo town (Noor et al. 2012). The feeding pressure is likely to impact on calf nutrition in the absence of supplementary feeding; this could lead to increased susceptibility to disease incidences and malnutrition. Low quality and quantity feeding has been associated with high calf losses in cow dairy herds (Ombura et al. 2007).

Markets drive the demand for camel milk in the periurban herds (Guliye et al. 2007), and this intensifies the competition for milk between humans and calves, as more milk is supplied to markets. This leads to poor calf health in the absence of commercial feed supplementation. Malnutrition was reported as a major cause of camel loss resulting from increased competition between human beings and calves in earlier studies (Schwartz et al. 1983; Baumann and Zessin 1992). The marginal effect of access to veterinary services on the proportional loss implies that reduced heifer loss is associated with more frequent access to veterinary services. Often, the veterinarians are inadequately trained in camel health, husbandry and management, which could impact on the effectiveness and delivery of veterinary services. Consequently, camel herd owners often use ethno-veterinary alternatives for animal health cases.

Diseases cause the loss of heifers and were reported to generate additional costs through veterinary care and changes in management practices (Chilonda and Van 
Huylenbroeck 2001). However, wealth also influences access to veterinary services because of the ability to pay for private services (Ahuja et al. 2003). Veterinary intervention packages and improved veterinary care were reported to reduce camel calves' mortality (Simpkin 1985; Njanja and Gathuma 2007).

The marginal effect of security on the loss of a heifer implies that unsecured camel herds lost more breeding stock, which can be attributed to rustling/theft. Consequently, camel herds are forced to migrate to areas with limited access to pasture, water, markets and veterinary services. Insecurity is a cause of forced sale of stock at lower prices and unplanned dowry payment (Kaimba et al. 2011; Kinyua et al. 2011). Insecurity situations sometimes spill into urban centres too, from the rural conflicts over pastures and water (Fratkin and Roth 2005). Camel owners respond to insecurity by hiring armed home guards, which increases their cost of production.

The marginal effect of labour is that use of hired labour to carry out camel management activities increased the loss of heifers. On average, $77 \%$ of camel herds in the peri-urban reported using hired labour. Herd owners have less direct involvement with the routine management activities of their herds. Other studies reported that pastoralists reduce their mobility in order to access markets and social amenities (Fratkin and Roth 2005; Tura 2008). Consequently, indigenous knowledge of livestock husbandry is eroding, due to separation of the herd owners from carrying out herding activities.

\section{Conclusions}

Results from the study indicate that, on average, periurban camel herds lose $11.8 \%$ more of heifers, compared to pastoral herds, and this loss could be significantly reduced with improved access to veterinary services, herd owners actively engaging in herding and daily management and lastly improved security situation in the grazing pastures. The frequent cause of loss of heifers in peri-urban herds differs from the frequency in pastoral herds, reflecting differences in management practices.

\section{Competing interests}

The authors declare that they have no competing interests.

\section{Authors' contributions}

All authors participated in concept development, data collecting, analysis and interpretation. MGS produced this work from her Master's degree thesis under the supervision of $\mathrm{GO}$ and $\mathrm{BOB}$, who also reviewed the manuscript for scientific publication. All authors read and approved the manuscript.

\section{Authors' information}

$\mathrm{BOB}$ is an Associate Professor at the Department of Animal Sciences, Egerton University, Kenya. GO is a Senior Lecturer at the Department of Agricultural Economics and Agribusiness Management, Egerton University, Kenya and also the manager of Collaborative Masters of Science in Agricultural and Applied economics, African Economics Research Consortium (AAE). MGS is a graduate of AAE and currently a research officer at the Department of Socioeconomics and Applied Statistics, Kenya Agricultural Research Institute.

\section{Acknowledgements}

The authors acknowledge the support of Kenya Agricultural Research Institute (KARI) and Kenya Arid and Semi-Arid Lands (KASAL) project for funding this study. The authors wish to acknowledge African Economics Research Consortium (AERC) for a partial scholarship and award of research grant that supported the completion of the study. Technical and institutional support provided by Egerton University is highly appreciated. Sincere appreciation goes to the pastoralists of Isiolo County for availing data used in this study and for their time during interviews. The authors acknowledge the cooperation and guidance provided by the Ministry of Livestock, Isiolo County.

\section{Author details}

'Kenya Agricultural Research Institute (KARI), Box 147-60500, Marsabit, Kenya. ${ }^{2}$ Department of Agricultural Economics and Agribusiness Management, Egerton University, Box 536-20115, Egerton, Kenya. ${ }^{3}$ Livestock Production Systems Group, Department of Animal Sciences, Egerton University, Box 536-20115, Egerton, Kenya.

Received: 21 March 2013 Accepted: 26 July 2013

Published: 4 September 2013

\section{References}

Ahuja, V, D Umali-Deininger, and C Haan. 2003. Market structure and the demand for veterinary services in India. Agricultural Economics 29(1): 27-42. Baumann, MP, and KH Zessin. 1992. Productivity and health of camels (Camelus dromedarius) in Somalia: associations with trypanosomiasis and brucellosis. Tropical Animal Health and Production 24(3): 145-156.

Bebe, BO, AY Guliye, IM Noor, and P Muliro. 2007. Evolution of Isiolo peri-urban marketed camel milk system. Marsabit, Kenya: Paper contributed to the 12th Kenya Camel Forum (KCF). May 14-18.

Chilonda, P, and G Van Huylenbroeck. 2001. A conceptual framework for the economic analysis of factors influencing decision-making of small-scale farmers in animal health management. Reveu scientifique et technique office international des épizooties 20(3): 687-700. Accessed 30 August 2013

Fair, R, and D Jaffee. 1972. Methods of estimation for markets in disequilibrium. Econometrica 40(3): 497-514.

Fratkin, E, and EA Roth. 2005. Introduction: The social, health, and economic consequences of pastoral sedentarization in Marsabit District, northern Kenya. In As pastoralists settle: Social, health and economic consequences of pastoral sedentarization in Marsabit District, Kenya, ed. E Fratkin and EA Roth, 1-28. New York: Kluwer Academic Publishers.

Goetz, S. 1992. A selectivity model of household food marketing behaviour in subSaharan Africa. American Journal of Agricultural Economics 74(2): 444-452.

Greene, WH. 1993. Econometric analysis. New Yolk: Macmillan Publishing Company.

Greene, WH. 2003. Econometric analysis. New Jersey: Pearson Education International.

Gujarati, DN. 2003. Basic econometrics. New York: McGraw-Hill Publishers.

Guliye, AY, IM Noor, BO Bebe, and IS Kosgey. 2007. Role of camels (Camelus dromedarius) in the traditional lifestyle of Somali pastoralists in northern Kenya. Outlook on Agriculture 36(1): 29-34. doi:10.5367/000000007780223669.

Herlocker, DJ, SB Shaaban, and S Wilkes. 1993. Range management handbook of Kenya, volume 2, 5th ed. Isiolo District: Ministry of Agriculture, Livestock Development and Marketing, Nairobi.

Kaimba, GK, BK Njehia, and AY Guliye. 2011. Effect of cattle rustling and household characteristics on migration decisions and herd size among pastoralists in Baringo District, Kenya. Pastoralism: Research, Policy and Practice 1(1): 18. doi:10.1186/2041-7136-1-18.

Kaufmann, BA. 2000. Camel calve losses and calf care measures in pastoral herds of northern Kenya: A system view. Revue d'Élevage et de Médecine Vétérinaire des Pays Tropicaux 53(2): 137-144.

Kaufmann, BA. 2003. Differences in perception of causes of camel calf losses between pastoralists and scientists. Experimental Agriculture 39(4): 363-378

Kaufmann, BA. 2005. Reproductive performance of camels (Camelus dromedarius) under pastoral management and its influence on herd development. Livestock Production Science 92(1): 17-29. doi:10.1016/j. livprodsci.2004.06.016.

Kinyua, KG, GA Yakub, NB Kamau, and HK Bett. 2011. Livestock marketing decisions among pastoral communities: The influence of cattle rustling in 

Development 1(3): 123-137.

Maddala, GS. 1992. Introduction to econometrics. New York: Macmillan Publishing Company.

Mundlak, Y. 2002. Handbook of agricultural economics. In Production and supply: Theory and estimation, ed. B Gardner and G Rausser, 3-85. Amsterdam: Elsevier.

Njanja, JC, and JM Gathuma. 2007. Major factors associated with high morbidity, mortality and performance of camel calves, kids and lambs in Rendille and Samburu pastoral herds in Marsabit District, Kenya. http://erepository.uonbi. ac.ke:8080/handle/123456789/6427. Accessed 21 June 2013.

Noor, IM, BO Bebe, and AY Guliye. 2012. Analysis of an emerging peri-urban camel production in Isiolo County, northern Kenya. Journal of Camelid Science 5: 41-61.

Ombura, J, JW Wakhungu, RO Mosi, and JO Amimo. 2007. An assessment of the efficiency of the dairy bull dam selection methodology in Kenya: livestock research for rural development, volume 19 article number10. http://www.lrrd. org//rrd19/1/ombu19010.htm. Accessed 20 June 2013.

Paris, Q. 1992. The von Liebig hypothesis. American Journal of Agricultural Economics 74(4): 1019-1028.

Petrie, A, and P Watson. 1999. Statistics for veterinary and animal science. Oxford: Blackwell Science.

Ransom, JK, K Paudyal, and K Adhikari. 2003. Adoption of improved maize varieties in the hills of Nepal. Journal of Agricultural Economics 29(3): 299-305.

Schwartz, HJ, R Dolan, and AJ Wilson. 1983. Camel production in Kenya and its constraints I: productivity. Tropical Animal Health and Production 15(3): 169-178.

Seré, CA, A Ayantunde, A Duncan, A Freeman, M Herrero, S Tarawali, and I Wright 2008. Livestock production and poverty alleviation-challenges and opportunities in arid and semi-arid tropical rangeland based systems. http://www.slideshare. net/LRI/china-grasslands-congress-june-16-V3. Accessed 20 June 2013.

Simpkin, SP. 1985. The effects of diseases as constraints to camel production in Northern Kenya. In Integrated project on Arid Lands (IPAL) technical report E-7, ed. United Nations Educational, Scientific, and Cultural Organization (UNESCO) programme on man and the biosphere, 76-160. Nairobi: UNESCO.

Swift, J. 1981. Rapid appraisal and cost-effective participatory research in dry pastoral areas of West Africa. Agricultural Administration 8(6): 485-492.

Thornton, P, M Herero, A Freeman, O Mwai, E Rege, P Jones, and J McDermott. 2007. Vulnerability, climate change and livestock-research opportunities and challenges for poverty alleviation, Journal of SAT Agricultural Research (SAT eJournal /ejournal.icrisat.org). http://www.icrisat.org/journal/ SpecialProject/sp7.pdf. Accessed 30 August 2013.

Tobin, J. 1958. Estimation of relationships for limited dependent variables. Econometrica 26(1): 24-36.

Tura, I. 2008. The histories of sheep and goat breeds and social mechanisms influencing their breeding among the Gabbra and the Rendille pastoralists of northern Kenya. http://208.100.23.11/images/stories/theses/THE\%2OHISTORIES\% 20OF\%20SHEEP\%20AND\%20GOAT\%20BREEDS\%20AND\%20SOCIAL\% 20MECHANISMS.pdf. Accessed 20 June 2013.

Verbeek, M. 2000. A guide to modern econometrics. New York: John Wiley \& Sons.

Wilson, RT. 1986. Reproductive performance and survival of young one humped camels on Kenya commercial ranches. Animal Production 42(3): 375-380.

doi:10.1186/2041-7136-3-23

Cite this article as: Shibia et al:: Evaluation of losses of replacement heifers in pastoral and peri-urban camel herds in semi-arid northern Kenya. Pastoralism: Research, Policy and Practice 2013 3:23.

\section{Submit your manuscript to a SpringerOpen ${ }^{\circ}$ journal and benefit from:}

- Convenient online submission

- Rigorous peer review

- Immediate publication on acceptance

- Open access: articles freely available online

- High visibility within the field

- Retaining the copyright to your article

Submit your next manuscript at $\gg$ springeropen.com 